\title{
Function of abnormal corpora lutea in vitro after GnRH-induced ovulation in the anoestrous ewe*
}

\author{
M. G. Hunter, J. A. Southee and G. E. Lamming \\ A.F.R.C. Research Group on Hormones and Farm Animal Reproduction, University of Nottingham, \\ Faculty of Agricultural Science, Sutton Bonington, Loughborough, Leics LE12 5RD, U.K.
}

\begin{abstract}
Summary. Normal and abnormal corpora lutea were recovered from anoestrous Romney Marsh ewes on Days 3, 4, 5 and 6 after treatment with small-dose (250 ng) multiple injections of GnRH followed by a bolus injection $(125 \mu \mathrm{g})$ with $(+\mathrm{P})$ and without $(-\mathrm{P})$ progesterone pretreatment and a study made of their characteristics in vitro. Plasma progesterone concentrations initially rose concurrently in all animals but abnormal luteal function occurred in $70 \%$ of the $-\mathrm{P}$ ewes and was defined on Day 5 when plasma progesterone concentrations declined relative to those in the $+\mathrm{P}$ ewes.

All corpora lutea recovered on Days 3 and 4 appeared macroscopically similar and there were no significant differences between the $+\mathbf{P}$ and $-\mathbf{P}$ groups in terms of luteal weight, progesterone content and binding of ${ }^{125} \mathrm{I}$-labelled hCG on these days. However, corpora lutea from the $-\mathrm{P}$ animals only exhibited a decline in progesterone production in vitro on Day $4(P<0.01)$, and morphological differences became apparent on Days 5 and 6 when the abnormal corpora lutea from the $-P$ animals also decreased in weight $(P<0.01)$ and progesterone content $(P<0.001)$. Binding of ${ }^{125}$ I-labelled hCG increased on Day 5 in the normal corpora lutea only.

These results show that, although abnormal luteal function induced by GnRH treatment of anoestrous ewes could not be distinguished from normal corpora lutea before Day 5 by measurement of progesterone in peripheral plasma, a significant decline in progesterone production in vitro occurred on Day 4 in the abnormal corpora lutea. This was followed by significant decreases in weight and progesterone content and a failure to increase ${ }^{125}$ I-labelled hCG binding. Abnormal corpora lutea are therefore capable of some initial growth and progesterone production, before undergoing a rapid and premature regression from Day 4, which has similar characteristics to natural luteolysis.
\end{abstract}

Keywords: abnormal luteal function; in vitro; sheep; anoestrus

\section{Introduction}

Southee et al. (1988) have confirmed that progesterone pretreatment ensured normal luteal function in anoestrous ewes after ovulation induced by $48 \mathrm{~h}$ of small-dose multiple injections of $\mathrm{GnRH}$ (McLeod et al., 1982). In the absence of progesterone priming, about $70 \%$ of the animals treated exhibited abnormal luteal function. These abnormal corpora lutea produced a transient rise in peripheral plasma progesterone, reaching $0.5-1.0 \mathrm{ng} / \mathrm{ml}$ for $1-2$ days before returning to baseline. The initial rise in plasma progesterone from the abnormal corpora lutea appeared similar to that produced in the $+\mathrm{P}$ animals and in the $30 \%$ of $-\mathrm{P}$ animals exhibiting normal luteal function (Southee $\mathrm{et}$ al., 1988).

*Reprint requests to Dr M. G. Hunter. 
The purpose of this study was to recover abnormal corpora lutea at different stages of their short functional life-cycle and investigate changes in weight, progesterone content, hCG binding and progesterone synthesis in vitro in an attempt to understand the basis of the abnormal function. Therefore, corpora lutea were recovered on Days 3 and 4 after the induced LH surge when plasma progesterone concentrations were increasing in all animals and on Days 5 and 6 when they were continuing to increase in animals showing normal luteal function, but declining in animals exhibiting abnormal luteal function.

\section{Materials and Methods}

Animals. Anoestrous Romney Marsh ewes (approximate body weight, $60 \mathrm{~kg}$ ) were housed and treated in a wellventilated building under conditions of natural daylength and temperature during the summer months. They were fed a diet of hay and 'indoor' concentrates with water always available.

Treatment and sampling procedures. Ovulation was induced using a modification of the injection regimen of McLeod et al. (1982). Multiple injections of $250 \mathrm{ng} \mathrm{GnRH}$ (Lutal; Fabwerke Hoechst AG, Frankfurt, West Germany) in $2 \mathrm{ml}$ sterile saline $(0.154 \mathrm{M}-\mathrm{NaCl})$ were administered via an indwelling jugular vein catheter. Ewes pretreated with progesterone received 3 implants (Sil-Estrus; Ceva, Paris, France) containing $375 \mathrm{mg}$ progesterone inserted subcutaneously in the axilla region 10 days before the start of $\mathrm{GnRH}$ treatment and removed at the time of the second injection. The treatment regimens, and numbers and distribution of animals between the experimental groups are outlined in Table 1. The $+\mathrm{P}$ animals were treated with 2-h injections of GnRH for $36 \mathrm{~h}$ and the $-\mathrm{P}$ animals for $18 \mathrm{~h}$ at which times all animals received a bolus injection of $125 \mu \mathrm{g} \mathrm{GnRH}$. The bolus injection was designed to synchronize the time of the preovulatory LH surge, and the time of its administration was determined from the actual times of the spontaneous LH surge induced by multiple injection of low doses of GnRH treatment (Southee et al., 1988).

Blood samples for assay of LH (3 ml) were taken at 2-h intervals via the catheter immediately before each pulsed injection of GnRH for the period of GnRH administration, and for $8 \mathrm{~h}$ after the bolus injection of $\mathrm{GnRH}$.

Blood samples for assay of progesterone $(5-10 \mathrm{ml})$ were taken by jugular venepuncture at 12 -h intervals for 5 days from the start of GnRH treatment and then daily for a total of 10 days from animals in Groups 1 and 6, and at 12-h intervals from the start of $\mathrm{GnRH}$ treatment until the day of slaughter from all other animals.

Collection of corpora lutea. Animals were slaughtered on Days 3, 4, 5 and 6 after the bolus injection according to Table 1. Corpora lutea were dissected from the ovaries within $30 \mathrm{~min}$ of slaughter, then weighed and their gross morphology noted. Individual corpora lutea were sliced to produce sections $0.35( \pm 0.02) \mathrm{mm}$ thick and weighed sections of tissue (20-50 mg) were stored in liquid nitrogen for subsequent assay of binding of ${ }^{125} \mathrm{I}$-labelled hCG, and at $-20^{\circ} \mathrm{C}$ for assay of progesterone content.

In-vitro incubations. All tissue incubations were carried out in $2 \mathrm{ml}$ Eagles Basal Medium (BMEM) containing $20 \mathrm{~mm}$-Hepes buffer (Flow Laboratories) and $0.1 \%$ bovine serum albumin (BSA; Fraction V; Sigma Chemical Co., Poole, Dorset, U.K.) at $37^{\circ} \mathrm{C}$ in a shaking water bath. Tissue slices were cut into segments $(2-10 \mathrm{mg})$ and distributed so that a representative section of each individual corpus luteum was incubated to determine basal progesterone production in vitro, the response to the addition of $\mathrm{LH}(100 \mathrm{ng} / \mathrm{ml})$, and the response to the addition of $\mathrm{LH}(100 \mathrm{ng} /$ $\mathrm{ml})$ plus pregnenolone $(1 \mu \mathrm{g} / \mathrm{ml})$. After incubation the slices were weighed and the media and tissue stored at $-20^{\circ} \mathrm{C}$ for subsequent progesterone assay. Tissue progesterone content was measured in ethanol extracts of incubated and non-incubated tissue slices which had been homogenized in a total of $5 \mathrm{ml}$ double-distilled ethanol using a polytron homogenizer at half maximum speed for $30 \mathrm{sec}$.

Binding of ${ }^{125}$ I-labelled $h C G$ to luteal tissue. Binding was assessed by using $\mathrm{hCG}$ labelled with ${ }^{125} \mathrm{I}$ by the lactoperoxidase method of Thorell \& Johansson (1971). The optimum incubation conditions for the binding of ${ }^{125}$ I-labelled hCG to sheep luteal tissue were determined by incubating tissue homogenate at $37^{\circ} \mathrm{C}$ and $22^{\circ} \mathrm{C}$ for $1-24 \mathrm{~h}$. A slightly higher specific binding was achieved at $22^{\circ} \mathrm{C}$ and for practical purposes binding assays were routinely incubated at $22^{\circ} \mathrm{C}$ for $16 \mathrm{~h}$, at which time a constant and maximum equilibrium was maintained. The binding capacity left in the supernatant was minimal at $<3 \%$. The addition of 200000 c.p.m. ${ }^{125}$ I-labelled hCG was found to be saturating, and binding increased with increasing amounts of tissue. The bindability of the preparation was $37 \%$.

The specific activity of the ${ }^{125}$ I-labelled hCG was determined by dividing the c.p.m. of the $50 \% \mathrm{~B} / \mathrm{F}$ from an inhibition curve by the quantity (ng) of unlabelled hCG that displaced $50 \%$ of the ${ }^{125}$ I-labelled hCG and for this preparation was calculated to be $18 \cdot 3 \mu \mathrm{Ci} / \mu \mathrm{g}$.

Specificity of ${ }^{125}$ I-labelled hCG binding to the luteal tissue was determined by the incubation of luteal homogenate with increasing amounts (1-1000 ng/tube) of the unlabelled hormones, hCG (Cr-121), LH (NIAMDD-oLH-24), FSH (NIH-FSH-S14) and prolactin (NIH-P-S10) and a constant amount of ${ }^{125}$ I-labelled hCG (200000 c.p.m.) (Fig. 1). Binding of ${ }^{125}$ I-labelled hCG could be completely inhibited by $100 \mathrm{ng}$ hCG and less so by $100 \mathrm{ng} \mathrm{LH}$, illustrating the greater affinity of hCG, while FSH and prolactin showed negligible cross-reactivity.

A Scatchard analysis was carried out on the tissue using 5000-1000000 c.p.m. ${ }^{125}$ I-labelled hCG. The dissociation constant $\left(K_{\mathrm{d}}\right)$ was calculated to be $80 \times 10^{-12} \mathrm{M}$ and the concentration of unoccupied binding sites $(\mathrm{Ru})$ 


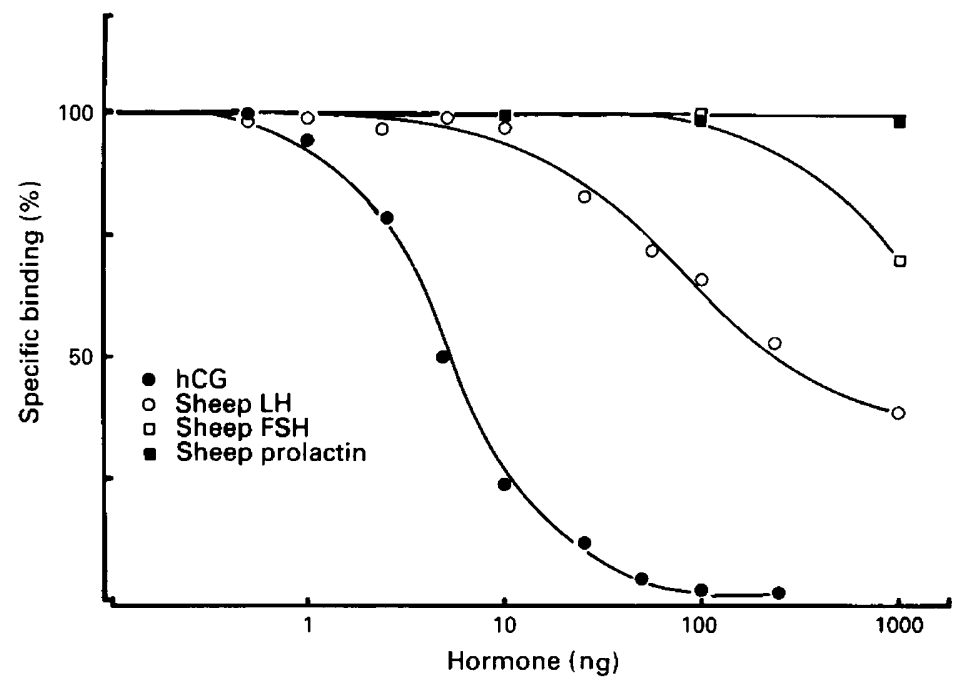

Fig. 1. Specificity of binding of ${ }^{125} \mathrm{I}$-labelled hCG to ovine luteal tissue determined using increasing concentrations of unlabelled hormones. Incubations were carried out at $22^{\circ} \mathrm{C}$ for $16 \mathrm{~h}$.

to be $20 \times 10^{-12} \mathrm{M} / \mathrm{mg}$ luteal tissue. Weighed slices of the luteal tissue (30-50 mg) were homogenized in a total of $5 \mathrm{ml}$ PBS-BSA on ice for $20 \mathrm{sec}$ using a polytron homogenizer at half maximum speed, and then centrifuged for $30 \mathrm{~min}$ at $3000 \mathrm{~g}$ and $4^{\circ} \mathrm{C}$. The resulting pellet was resuspended in a volume of PBS-BSA calculated to produce the final concentration of $5 \mathrm{mg}$ tissue in $100 \mu \mathrm{l}$ buffer.

To determine total binding of ${ }^{125} \mathrm{I}$-labelled hCG, $100 \mu \mathrm{l}$ samples of the tissue suspension were incubated in triplicate in plastic tubes, with $100 \mu{ }^{125}$ I-labelled hCG $(200000$ c.p.m. $)$ and $100 \mu \mathrm{l}$ PBS-BSA to make a final volume of $300 \mu \mathrm{l}$, at $22^{\circ} \mathrm{C}$ in a shaking water bath for $16 \mathrm{~h}$. Non-specific binding (NSB) was determined by incubating $100 \mu \mathrm{l}$ samples of tissue suspension with $100 \mu \mathrm{l}^{125} \mathrm{I}$-labelled hCG, and an excess of unlabelled hCG (100 i.u. in $100 \mu \mathrm{l}$; Sigma Chemical Co.).

The reaction was stopped by the addition of $2 \mathrm{ml}$ ice-cold PBS-BSA. The tubes were centrifuged at $3000 \mathrm{~g}$ for $30 \mathrm{~min}$ at $4^{\circ} \mathrm{C}$, the supernatant aspirated and the tissue pellet resuspended in a further $2 \mathrm{ml}$ PBS-BSA and recentrifuged. The supernatant was again aspirated and the final pellet counted on a gamma counter (counting efficiency = $75 \%$ ) for $1 \mathrm{~min}$. Specific binding was defined as the difference between total binding and non-specific binding and expressed as c.p.m. bound/CL. The non-specific binding as a proportion of total binding ranged from 6 to $36 \%$.

Hormone radioimmunoassays. Concentrations of $\mathrm{LH}$ in peripheral plasma were determined by the specific doubleantibody radioimmunoassay of Foster \& Crighton (1974) as modified by McLeod et al. (1982). Within this study the limit of sensitivity of the assay was $0.3 \mathrm{ng}$ (NIAMDD-oLH-24) equiv./ml plasma and the inter- and intra-assay coefficients of variation were 10.9 and $7.3 \%$ respectively. Measurement of progesterone concentration in peripheral plasma was based on the radioimmunoassay method of Haresign et al. (1975) as modified by Hunter et al. (1986). The assay showed negligible cross-reaction with other major steroids and within this study the limit of sensitivity was $0.1 \mathrm{ng} / \mathrm{ml}$, the mean extraction efficiency was $83.4 \pm 0.67 \%$ and inter- and intra-assay coefficients of variation were $12 \cdot 6$ and $9.5 \%$ respectively.

Concentrations of progesterone in incubation media (BMEM-BSA) were measured using the same method as above but without extraction. The direct assay of media samples was validated by comparing the values recorded from the measurement of a range of standards in BMEM-BSA with and without prior extraction. The linear correlation coefficient of progesterone recovered with and without extraction was $0.99(P<0.01)$, indicating that the direct assay of progesterone in culture medium was appropriate. Inter- and intra-assay coefficients of variation were $12 \cdot 2$ and $7.4 \%$ respectively. The cross-reactivity of pregnenolone with the antiserum was $<0.001 \%$, and blanks were included in the assay which contained $100 \mu \mathrm{l}$ medium containing $\mathrm{I} \mu \mathrm{g}$ pregnenolone/ml. These blanks showed no cross-reactivity, and furthermore all medium samples were diluted at least 10 -fold before assay.

Aliquants $(100 \mu \mathrm{l})$ of the ethanol extract were evaporated to dryness in extraction tubes and redissolved in assay buffer for direct assay of tissue progesterone content. The volume of buffer added to the tubes was adjusted to between 1 and $10 \mathrm{ml}$ to obtain a value of $\mathrm{B} / \mathrm{B}_{0}$ in the assay of between 30 and $80 \%$. The recovery of progesterone at the different dilutions was determined using $\left[{ }^{3} \mathrm{H}\right]$ progesterone $(100 \mu \mathrm{l} ; 30000 \mathrm{c.p} . \mathrm{m}$.) in double-distilled ethanol and was taken into account in the calculation of results within each assay. Dilutions of extracted samples exhibited parallelism to the standard curve, and ethanol and buffer blanks were below the limit of sensitivity of the assay which 
was $0.1 \mathrm{ng} / \mathrm{ml}$. Inter- and intra-assay coefficients of variation were $11.8 \%$ and $8.4 \%$ respectively for ethanol extracts containing progesterone at a concentration of $100 \mathrm{ng} / \mathrm{ml}$.

Statistical analysis. Analysis of variance was carried out on balanced groups of randomly selected replicates from each experimental group (Table 1). Comparisons were made between the normal corpora lutea recovered from the $+P$ animals and all the corpora lutea recovered from $-P$ animals slaughtered on Days 3 and 4 (Groups 2, 3, 7 and 8). On Days 5 and 6, the normal corpora lutea (Groups 4 and 5) were compared only with those defined as abnormal from Groups 9 and 10 , according to the plasma progesterone profiles. The mean values of the individual groups were compared using the least significant difference test (Keppel, 1973).

\section{Results}

The ovulatory response and incidence of luteal function in all the animals is shown in Table 1.

Table 1. The ovulatory response and luteal function in anoestrous Romney Marsh ewes treated with small-dose multiple injections of GnRH $(250 \mathrm{ng} / 2 \mathrm{~h}$ ) followed by a bolus injection (125 $\mu \mathrm{g})$ after (a) $36 \mathrm{~h}$ following 10 days progesterone pretreatment $(+P)$ and $(b)$ after $18 \mathrm{~h}$ without progesterone pretreatment

$$
(-\mathrm{P})
$$

\begin{tabular}{|c|c|c|c|c|c|c|c|}
\hline \multirow[b]{3}{*}{ Group } & \multirow{3}{*}{$\begin{array}{l}\text { Time of slaughter } \\
\text { (days after } \\
\text { bolus injection) }\end{array}$} & \multicolumn{3}{|c|}{ Ovulatory response } & \multicolumn{3}{|c|}{ Luteal function } \\
\hline & & \multicolumn{2}{|c|}{ No. of animals } & \multirow{2}{*}{$\begin{array}{l}\text { Ovulation } \\
\text { rate }\end{array}$} & \multicolumn{2}{|c|}{ No. of animals $(\%)$} & \multirow{2}{*}{$\begin{array}{l}\text { No. of CL } \\
\text { in final } \\
\text { analysis }\end{array}$} \\
\hline & & Treated & Ovulated $(\%)$ & & Normal & Abnormal & \\
\hline \multirow[t]{5}{*}{ (a) } & - & 5 & $5(100)$ & - & $5(100)$ & 0 & - \\
\hline & 3 & 10 & $5(50)$ & $1 \cdot 20$ & $5(100)$ & 0 & 4 \\
\hline & 4 & 13 & $11(85)$ & $1 \cdot 50$ & $11(100)$ & 0 & 11 \\
\hline & 5 & 18 & $16(88)$ & 1.25 & $16(100)$ & 0 & 16 \\
\hline & 6 & 10 & $9(90)$ & $1 \cdot 10$ & $9(100)$ & 0 & 5 \\
\hline Total & & 56 & $46 \quad(82)$ & $1 \cdot 30$ & $46(100)$ & & - \\
\hline \multirow[t]{5}{*}{ (b) } & - & 10 & $8(80)$ & - & $3 \quad(37)$ & $5(63)$ & - \\
\hline & 3 & 10 & $8(80)$ & $1 \cdot 50$ & Undefined & & 4 \\
\hline & 4 & 15 & $13(87)$ & 1.40 & Undefined & & 11 \\
\hline & 5 & 25 & $20(80)$ & $1 \cdot 50$ & $7(35)$ & $13(65)$ & 16 \\
\hline & 6 & 10 & $7(70)$ & $1 \cdot 10$ & $2(28)$ & $5(72)$ & 5 \\
\hline Total & & 70 & $56(80)$ & $1 \cdot 40$ & - & - & - \\
\hline
\end{tabular}

\section{Plasma LH concentrations}

Plasma LH concentrations remained at basal levels $(<2 \mathrm{ng} / \mathrm{ml})$ during the period of pulsatile GnRH treatment. All animals responded to the bolus injection by producing an immediate preovulatory-type LH surge reaching peak values of between 15 and $62 \mathrm{ng} / \mathrm{ml}$.

\section{Progesterone profiles}

The mean progesterone profile of the $+\mathrm{P}$ animals in Group 1 treated with $\mathrm{GnRH}$ for $36 \mathrm{~h}$ is shown in Fig. 2. All animals exhibited peripheral plasma progesterone concentrations indicative of normal luteal function; concentrations rose 3 days after the bolus injection reaching a plateau at Day 6, with mean peak values of $2-2.5 \mathrm{ng} / \mathrm{ml}$ which were maintained for the course of the experiment.

Of the 8 animals in Group 5 which ovulated in response to $18 \mathrm{~h}$ of $\mathrm{GnRH}$ treatment without progesterone pretreatment, 5 exhibited progesterone profiles similar to those associated with abnormal luteal function (Southee et al., 1988). Progesterone concentrations rose in these animals 


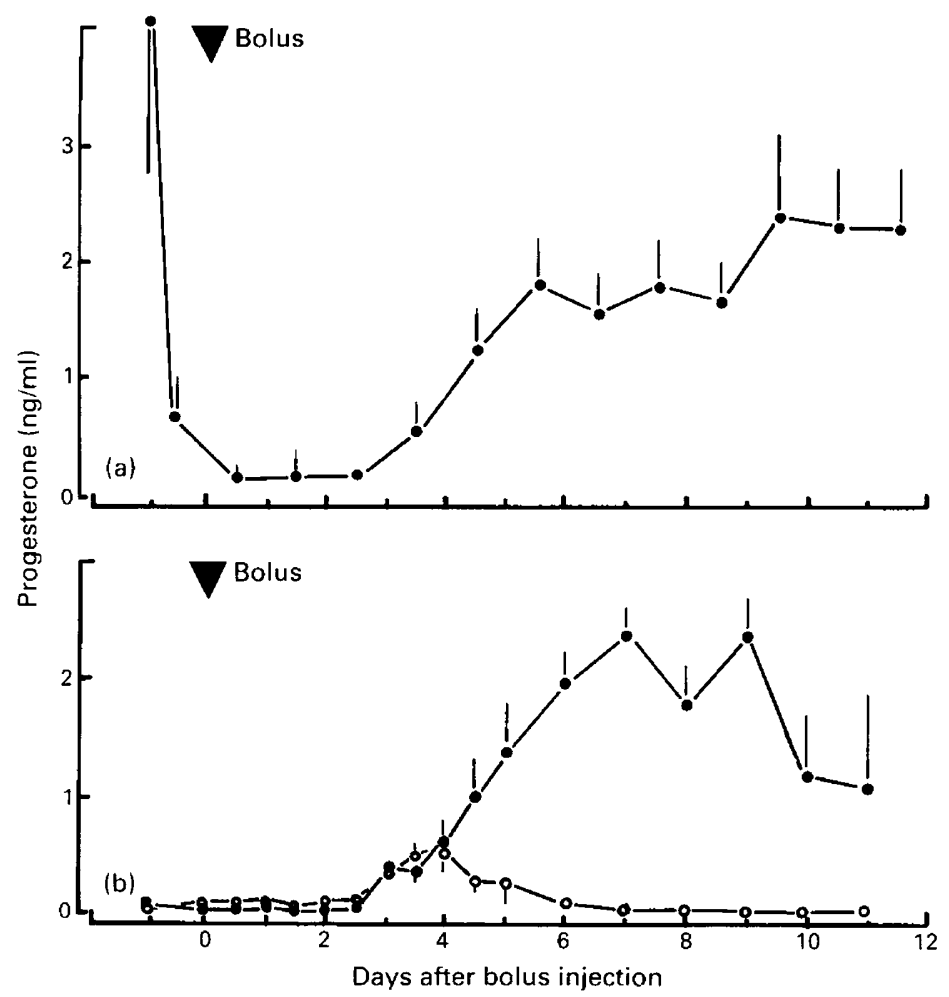

Fig. 2. Progesterone profiles (mean \pm s.e.m.) of anoestrous ewes treated with small-dose multiple injections of GnRH $(250 \mathrm{ng} / 2 \mathrm{~h})$ plus a bolus injection of GnRH $(125 \mu \mathrm{g})$ in (a) $+\mathrm{P}$ ewes treated for $36 \mathrm{~h}(\mathrm{~N}=5)$ (Group 1) and (b) $-\mathrm{P}$ ewes treated for $18 \mathrm{~h}$ (Group 6). $=$ normal luteal function $(\mathrm{N}=3) ; \mathrm{O}=$ abnormal luteal function $(\mathrm{N}=5)$.

from Day $2,60 \mathrm{~h}$ after the bolus injection, to reach a mean peak value on Day 4 (96h) of $0 \cdot 6 \pm 0 \cdot 2 \mathrm{ng} / \mathrm{ml}$ before declining over the next $48 \mathrm{~h}$ to reach basal levels by Day 6 (Fig. 2). The remaining 3 animals produced normal luteal-phase patterns of progesterone production (Fig. 2). The coincident induction of the $\mathrm{LH}$ surge in all animals by the bolus injection of $\mathrm{GnRH}$ synchronized the initial rise in plasma progesterone concentrations throughout all the groups, irrespective of progesterone priming. There was no difference between the groups in progesterone concentration over the first 4 days after the bolus injection, although by Day 6 the progesterone production by the abnormal corpora lutea was significantly lower $(P<0.001)$.

All animals in the remaining experimental groups exhibited a similar rise in plasma progesterone concentration $60 \mathrm{~h}$ after the bolus injection of GnRH. When sampling was extended for $120 \mathrm{~h}$ or longer (Days 5 and 6; Groups 4, 5, 9 and 10), a decline in progesterone production was evident in a proportion of the $-\mathrm{P}$ animals after Day 4 (13/20, Group 9; 5/7, Group 10). Progesterone concentrations continued to rise in all of the $+\mathrm{P}$ animals (Groups 4 and 5) and were maintained for the period of sampling. None of the animals in the $-\mathbf{P}$ groups slaughtered on Day 3 or 4 exhibited any evidence of a decline in plasma progesterone concentration within the period of sampling.

\section{Ovarian morphology}

All the corpora lutea recovered on Days 3 and 4 from the $+P$ and $-P$ animals in Groups 2, 3, 7 and 8 appeared macroscopically similar, with their weights ranging from 30 to $120 \mathrm{mg}$ on Day 3 

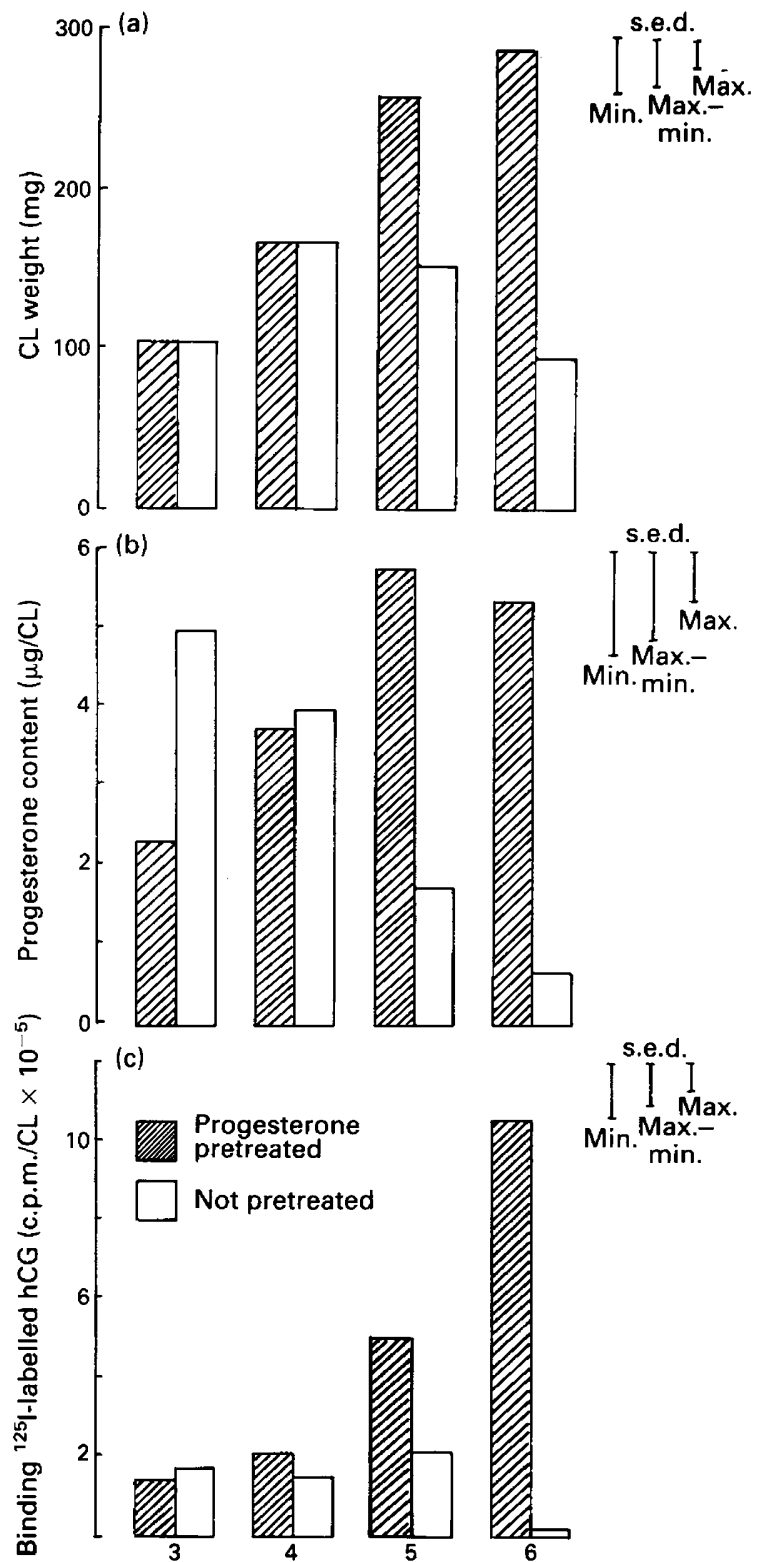

Fig. 3. Mean (a) weight, (b) progesterone content and (c) binding of ${ }^{125} \mathrm{I}$-labelled hCG to corpora lutea recovered on Day $3(N=4)$, Day $4(N=11)$, Day $5(N=16)$ and Day $6(N=5)$ following the induced LH surge from anoestrous ewes treated with $2 \mathrm{~h}$ injection of GnRH $(250 \mathrm{ng})$ plus a bolus injection $(125 \mu \mathrm{g})$ for $36 \mathrm{~h}$ after a period of progesterone pretreatment (normal) or $18 \mathrm{~h}$ without pretreatment (undefined normal/abnormal Days 3 and 4; abnormal only Days 5 and 6). s.e.d. = standard error of difference for comparing between individual treatment means; d.f. $=65$. 


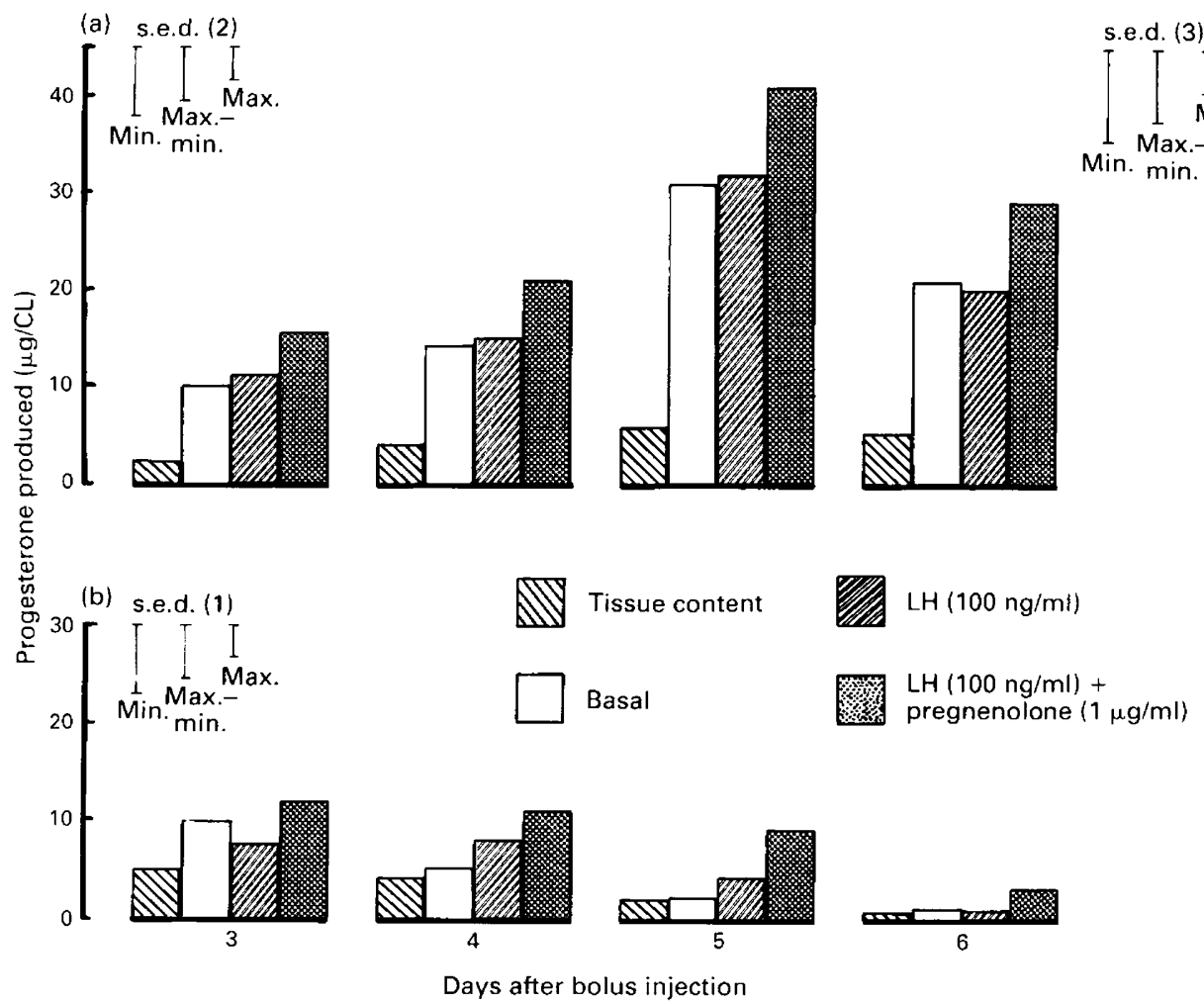

Fig. 4. Mean progesterone production in vitro by tissue slices from corpora lutea recovered on Day $3(\mathrm{~N}=4)$, Day $4(\mathrm{~N}=11)$, Day $5(\mathrm{~N}=16)$ and Day $6(\mathrm{~N}=5)$ following the induced $\mathrm{LH}$ surge in anoestrous ewes treated with small-dose multiple injections of GnRH $(250 \mathrm{ng} / 2 \mathrm{~h})$ plus a bolus injection of GnRH $(125 \mu \mathrm{g})$ in (a) $+\mathrm{P}$ ewes treated for $36 \mathrm{~h}$, showing normal luteal function, and (b) $-P$ ewes treated for $18 \mathrm{~h}$, showing undefined luteal function on Days 3 and 4 and defined abnormal function only on Days 5 and 6. s.e.d. (1) and s.e.d. (2) represent standard errors of difference for comparing between any individual treatment means of the same CL type; d.f. $=128$. s.e.d. (3) represents standard error of difference for comparing between any individual treatment means for different $\mathrm{CL}$ types; d.f. $=65$.

and 90 to $300 \mathrm{mg}$ on Day 4 . The corpora lutea recovered from the $+\mathbf{P}$ animals in Groups 4 and 5 on Days 5 and 6 were slightly larger, with weights of $100-420 \mathrm{mg}$ on Day 5 and $100-470 \mathrm{mg}$ on Day 6 , which were similar to the weights of the corpora lutea recovered from the $-P$ animals in Groups 9 and 10 that produced normal plasma progesterone profiles.

In contrast, the corpora lutea recovered from the remaining $-\mathbf{P}$ animals were smaller and pale in colour so that two populations of corpora lutea could be distinguished and identified as being normal or abnormal, concordant with the results of the plasma progesterone analysis.

\section{Analysis of in-vitro characteristics}

The results of the in-vitro investigations are shown in Figs 3 and 4 and, in all the characteristics measured, the analysis revealed significant overall effects between the two types of corpora lutea $(P<0.05)$ with the abnormal corpora lutea producing a lower overall mean than did the normal. There was also a significant effect of day of collection and a significant corpus luteum type $\times$ day of collection interaction to at least the $P<0.05$ level. 
The weight, luteal progesterone content and binding of ${ }^{125} \mathrm{I}$-labelled hCG of the two types of corpora lutea were not significantly different on Days 3 and 4 with differences between corpus luteum type only emerging on Day 5 . The weights of the corpora lutea from the $+\mathrm{P}$ and $-\mathrm{P}$ ewes increased between Days 3 and 4 and a difference $(P<0.001)$ only arose on Day 5 as the mean weight of the abnormal corpora lutea decreased coincident with an increase in weight of the normal corpora lutea (Fig. 3a). While the normal corpora lutea continued to develop, the abnormal corpora lutea showed signs of regression, leading to the greatest difference in weights between the two types on Day 6 (normal, $282 \mathrm{mg}$; abnormal, $94.2 \mathrm{mg} ; P<0.001$ ).

A similar relationship between the two types of corpora lutea on Days 5 and 6 was reflected in the pattern of change in luteal progesterone content (Fig. 3b). Binding of ${ }^{125} \mathrm{I}$-labelled hCG to the tissue from $+\mathrm{P}$ and $-\mathrm{P}$ ewes was not different on Days 3 and 4 and, similar to the change in weight and luteal progesterone content, a difference in ${ }^{125} \mathrm{I}$-labelled hCG binding emerged on Day 5 $(P<0.001)$ (Fig. 3c). However, this difference was due to the increase in binding to the normal tissue. Binding to the abnormal tissue remained fairly constant until Day 6 , at which time it fell dramatically.

There was no difference in in-vitro progesterone production, basal or with additional LH or pregnenolone, between the corpora lutea from $+\mathbf{P}$ or $-\mathbf{P}$ animals on Day 3 . A significant difference emerged on Day $4(P<0.01)$ due to the decline in basal progesterone output from the corpora lutea from $-P$ ewes which continued to decrease over the subsequent days as progesterone production from normal tissue continued to increase (Fig. 4). There was a significant effect on the tissue of treatment $(P<0.01)$, with pregnenolone consistently increasing progesterone production. However, the addition of $\mathrm{LH}$ at a final concentration of $100 \mathrm{ng} / \mathrm{ml}$ did not significantly enhance progesterone production from either type of tissue.

\section{Discussion}

The culmination of the multiple low-dose GnRH treatment with a bolus injection just before the time when the LH surge was anticipated was successful in synchronizing the occurrence of the LH surge in all animals. The initial parallel rises in plasma progesterone in the $+\mathbf{P}$ and $-\mathbf{P}$ animals (Fig. 2) suggest that ovulation was also synchronized and, therefore, the corpora lutea recovered from all animals were of comparable ages. The induction of the preovulatory $\mathrm{LH}$ surge after $18 \mathrm{~h}$ of treatment in the $-\mathrm{P}$ animals did not alter the incidence of normal luteal function which persisted at about $30 \%$ as found in other studies (McLeod et al., 1982; Southee et al., 1988).

The initial development of the proportion of abnormal corpora lutea produced in the $-\mathbf{P}$ animals appeared identical to that of the normal corpora lutea produced in the $+P$ animals. The plasma progesterone concentrations of all animals were similar for 4 days $(96 \mathrm{~h})$ after the bolus injection. During the same time period, the weights of all the corpora lutea recovered were also similar, as were the luteal progesterone concentration and the number of available binding sites for ${ }^{125}$ I-labelled hCG (Fig. 3c). By $108 \mathrm{~h}$ after the bolus injection the plasma progesterone concentration began to decline in a proportion of the $-\mathrm{P}$ animals (Fig. 2) and a decrease in luteal weight and progesterone content became apparent. The increase in weight between Days 3 and 4 may be influenced by the inclusion of the $30 \%$ of potentially normal corpora lutea, although it does suggest that the abnormal corpora lutea included within these groups are capable of some initial growth. A reduction in in-vitro progesterone production by the corpora lutea from the $-\mathrm{P}$ animals became apparent as early as Day 4 and was the first indication of a functional difference between normal and abnormal corpora lutea. Macroscopically, the two types of corpora lutea were still indistinguishable at this time, although differences were apparent on Day 5 when abnormal corpora lutea were pale in appearance whereas the normal corpora lutea remained dark pink in colour. 
The receptor content of the abnormal corpora lutea induced in this study did not exhibit the developmental increase measured in the normal corpora lutea on Day 5; although progesterone production in vitro fell on Day 4, hCG binding did not fall. In another study in which ovulation was induced in anoestrous ewes by three large single injections of GnRH, binding of ${ }^{125}$ I-labelled hCG to abnormal corpora lutea was maintained at a level similar to that recorded for normal corpora lutea 9 days after GnRH treatment (McNeilly et al., 1981). While these corpora lutea were longer lived than those induced by the small-dose multiple-injection regimen used here, both experiments suggest that a lack of gonadotrophin receptors is therefore probably not the fundamental cause of the observed premature regression.

In the present study, progesterone production in vitro was increased by the addition of pregnenolone. The response of the abnormal tissue to the supplementary supply of precursor suggests that the subnormal progesterone production may be caused by an inadequate supply of substrate. It may be that the young abnormal corpus luteum has sufficient substrate to provide for its initial development and transient output of progesterone, but exhausts its supply after $96 \mathrm{~h}$. It cannot be determined from these results whether this shows an inadequacy of substrate as a cause or a consequence of premature luteolysis. Available evidence suggests that this may be a consequence of regression; Armstrong \& Black (1966) reported that luteal tissue in vitro will respond to pregnenolone by increasing progesterone output after luteolysis has been initiated and is, therefore, yet another feature of regressing tissue.

The cellular composition of the corpus luteum might be implicated in the suboptimal function of the abnormal corpus luteum. Contemporary studies suggest that the component ratio of small to large cells within the corpus luteum plays an important role in its regulation and functional capacity (Niswender et al., 1985). However, O'Shea et al. (1984) concluded from a morphometric study of GnRH-induced abnormal corpora lutea that the relative proportions of large to small cells remained unchanged, although the smaller sized corpora lutea were composed of fewer, smaller cells. However, in anoestrous ewes treated with small-dose multiple injections of GnRH, there were no differences between the size or numbers of granulosa cells of ovulatory follicles in progesteroneprimed or non-primed ewes (Hunter et al., 1986). This supports the results of the present study, which showed that the abnormal corpora lutea exhibited an apparently normal initiation of growth and development and the similarities between normal and abnormal corpora lutea in weight and size suggest that the number of luteal cells is not a limiting factor.

A final possible cause of the short luteal phase might be due to the termination of luteal function by an external luteolytic factor, or increased sensitivity of the inadequate corpus luteum to circulatory levels of luteolysin as has been demonstrated in the post-partum cow (Troxel \& Kesler, 1984).

In conclusion, this experiment has allowed the comparison in vitro of normal and abnormal corpora lutea produced in anoestrous ewes after GnRH- induced ovulation and has provided evidence to suggest that the regressional characteristics that occur within the abnormal corpus luteum around Day 4-5 are similar to those which have been described at the end of the normal luteal phase (Armstrong \& Black, 1966; Diekman et al., 1978). These results, therefore, raise the question as to whether the premature regression of the short life-cycle corpus luteum is an inherent feature of the gland itself or is due to the influence of an external luteolytic factor. Such a question is clearly worthy of further study.

We thank the AFRC for financial support; NIH for standard hormone preparations and hCG for iodination; and Hoechst Pharmaceuticals for supplies of GnRH.

\section{References}

Armstrong, D.T. \& Black, D.L. (1966) Influence of luteinizing hormone on corpus luteum metabolism and pro- gesterone biosynthesis throughout the bovine estrous cycle. Endocrinology 78, 937-944. 
Diekman, M.A., O'Callaghan, P., Nett, T.M. \& Niswender, G.D. (1978) Effect of prostaglandin F2 $\alpha$ on the number of $\mathrm{LH}$ receptors in ovine corpora lutea. Biol. Reprod. 19, $1010-1013$.

Foster, J.P. \& Crighton, D.B. (1974) Luteinizing hormone (LH) release after single injections of a synthetic $\mathbf{L H}$ releasing hormone (LH-RH) in the ewe at three different reproductive stages and comparison with natural LH release at oestrus. Theriogenology 2, 87-100.

Haresign, W., Foster, J.P., Haynes, N.B., Crighton, D.B. \& Lamming, G.E. (1975) Progesterone levels following treatment of seasonally anoestrous ewes with synthetic LH-releasing hormone. J. Reprod. Fert. 43, 269-279.

Hunter, M.G., Southee, J.A., McLeod, B.J. \& Haresign, W. (1986) Progesterone pretreatment has a direct effect on GnRH induced preovulatory follicles to determine their ability to develop into normal corpora lutea in anoestrous ewes. J. Reprod. Fert. 76, $349-363$.

Keppel, G. (1973) Design and Analysis: A Researcher's Handbook. Prentice-Hall Inc., Englewood Cliffs.

McLeod, B.J., Haresign, W. \& Lamming, G.E. (1982) The induction of ovulation and luteal function in seasonally anoestrous ewes treated with small-dose multiple injections of Gn-RH. J. Reprod. Fert. 65, 215-221.
McNeilly, A.S., Hunter, M., Land, R.B. \& Fraser, H.M. (1981) Inadequate corpus luteum function after the induction of ovulation in anoestrous ewes by LH-RH or an LH-RH agonist. J. Reprod. Fert. 63, 137-144.

Niswender, G.D., Schwall, R.H., Fitz, T.A., Farin, C.E. \& Sawyer, H. R. (1985) Regulation of luteal function in domestic ruminants: new concepts. Recent Prog. Horm. Res. 41, 101-143.

O'Shea, J.D., Rodgers, R.J. \& Wright, P.J. (1984) Morphometric analysis and function in vivo and in vitro of corpora lutea from ewes treated with LHRH during seasonal anoestrus. J. Reprod. Fert. 72, 75-85.

Southee, J.A., Hunter, M.G. \& Haresign, W. (1988) Function of abnormal corpora lutea in vivo after $\mathrm{GnRH}$-induced ovulation in the anoestrous ewe. $J$. Reprod. Fert. 84, 131-137.

Thorrell, J.I. \& Johansson, B.G. (1971) Enzymatic iodination of polypeptides with ${ }^{125} \mathrm{I}$ to high specific activity. Biochem. Biophys. Acta 251, 363-369.

Troxel, T.R. \& Kesler, D.J. (1984) Ability of indomethacin to alter prostaglandin metabolite concentrations and to enhance the function of corpora lutea induced in post partum suckled beef cows. J. Anim. Sci. 59, $177-181$.

Received 21 December 1987 